Bangladesh J. Bot. 42(2): 295-300, 2013 (December)

\title{
EFFECTS OF CRUDE EXTRACT OF MICROCYSTIS AERUGINOSA KÜTZ. ON GERMINATION, GROWTH AND CHLOROPHYLL CONTENT OF ZEA MAYS L.
}

\author{
Mostafa M El-SheekH*, Hanan M Khairy ${ }^{1}$ and RANia El-Shenody \\ Department of Botany, Faculty of Science, Tanta University, Tanta-31527, Egypt \\ Key words: Microcystin-LR, Zea mays, Germination, Growth, Chlorophyll
}

\begin{abstract}
Effects of crude extract of Microcystis aeruginosa containing microcystin-LR on the germination, growth and chlorophyll content of Zea mays was studied. Soaking of Z. mays seeds for 24 hrs in the cell-free medium during death phase of $M$. aeruginosa induced a significant reduction in root, shoot lengths, number of lateral roots, fresh and dry weights, leaf area and pigment contents. Soaking of Z. mays seeds for 24 hours in different concentrations of crude extracts of M. aeruginosa $(100,200,300,500$ and $800 \mu \mathrm{g}$ dry cells $/ \mathrm{ml})$ from $\log$ phase showed inhibitory effect of growth parameters and germination.
\end{abstract}

\section{Introduction}

Toxic cyanobacteria produce cyanotoxins at high levels that can cause chronic and subchronic toxicities to animals, plants and human. Cyanotoxicity in eukaryotes was mainly focused on animals. However, the number of studies related to the impact of cyanotoxin on aquatic and terrestrial crop plants irrigated by water containing these toxins, was increased during last few years. The use of this contaminated irrigation water can also have an economical impact which is caused by the reduction of the germination rate of seeds, and alteration of the quality and the productivity of crop plants (Peuthert et al. 2007). In addition to crop and vegetable plants might accumulate microcystins in their edible tissues (Mohamed and Al-Shehri 2009), and therefore, these plants might contribute directly or indirectly to cyanotoxin transfer through the food chain, and thus constitute a potent health risk source (Saqrane et al. 2009).

Cyanotoxins contaminant as microcystins (MCs) in water utilized to irrigate food crop plants have not yet been considered within any official monitoring program on water quality. Previous studies clearly indicated that irrigation with water containing MCs can be a threat for both the quality and yield of crop plants. This fact highlights the need to examine the MCs threshold which may be detrimental to crops (Pflugmacher et al. 2006). Since then, the research interest on phytotoxic effects of cyanobacteria on terrestrial plants has increased, demonstrating morphological and physiological alterations by cyanotoxins in a range of terrestrial plants (Chen et al. 2004).

MCs can also affect seed germination, early state development, and chlorophyll content, Pflugmacher et al. (2006) reported that germination of alfalfa seeds was inhibited by both purified MCs and anatoxin-a from a toxic cyanobacteria bloom, and by a cell-free crude extract from the same bloom. Peuthert et al. (2007) reported the uptake of MC-LR and MC-LF by roots of seedling of 11 agricultural plants, and their translocation to shoots. Spray irrigation of commercial lettuce (Lactuca sativa) plants with water containing Microcystis resulted in colonies and single cells of

\footnotetext{
*Author for correspondence: <mostafaelsheekh@yahoo.com>. ${ }^{1}$ National Institute of Oceanography and Fisheries, Alexandria, Egypt.
} 
the Cyanobacterium when Microcystis was lodged on the leaves 10 days after the last irrigation (Codd et al. 1999). The use of this contaminated irrigation water have an economical impact which occurred by a reduction of the germination rate of seeds, and alteration of the quality and the productivity of crop plants (Saqrane et al. 2009).

The main objective of this work was to find out the eventual response to toxicity of cyanotoxins as the major agricultural impacts induced by the use of contaminated water for plant irrigation and effects of different concentrations of microcystin crude extract of Microcystis aeruginosa on the germination, growth and chlorophyll content of Zea mays.

\section{Materials and Methods}

Microcystis aeruginosa was isolated from River Nile channel near Tanta city, purified and identified according to Prescott (1978). M. aeruginosa was grown in medium Allen's and Stanier (1968) under continuous fluorescent illumination $\left(80 \mu \mathrm{mol} / \mathrm{m}^{2} / \mathrm{s}\right)$ at $25 \pm 2^{\circ} \mathrm{C}$.

Microcystin crude extract was prepared according to Harada et al. (1988). MicrocystinLR was estimated using high performance liquid chromatography (HPLC) according to Shen et al. (2003).

The dried material from extract was re-dissolved in minimal volume of sterilized distilled water to obtain the following concentrations of microcystin crude extract $(100,200,300,500,800$ $\mu \mathrm{g} / \mathrm{ml}$ ), distilled water was used as control. Growth parameters including percentage of germination, root and shoot lengths and number of lateral roots of seedling were measured after 4 days of germination.

Seeds of Zea mays (maize) were surface sterilized in 3.5\% sodium hypochlorite for 2.0 min rinsed several times with distilled water. Some seeds were soaked in the cell free medium of $M$. aeruginosa at two different growth phases (lag and death phase) for $24 \mathrm{hrs}$ and the same number of seeds were soaked in distilled water as control. Leaf areas of the seedlings were recorded using Ushikata x-plan 360d Planimeter (Featonby and Van Staden 1983). The photosynthetic pigments were estimated speectrophotometrically according to Metzner et al. (1965).

Results were presented as mean $\pm \mathrm{SD}$ for three replicates. The statistical analyses were carried out using SAS program (1989-1996) version 6.12. Data obtained were analyzed statistically to determine the degree of significance between treatments using one way analysis of variance (ANOVA) at $\mathrm{p} \leq 0.001$.

\section{Results and Discussion}

Soaking of maize seeds for $24 \mathrm{hrs}$ in the cell-free medium of $M$. aeruginosa induced a significant reduction in root lengths of seedlings. The most pronounced inhibition was observed in seedlings soaked in the cell-free medium during death phase leading to $76.7 \%$ decrease as compared to the control value after 8 days of germination (Table 1). In case of seeds treated with cell-free medium of log phase, the root length was decreased by $44.6 \%$. The shoot length was decreased by $97.6 \%$ as compared with death phase cell-free medium, while, seeds treated with cell-free medium from log phase, shoot length of maize seedlings was decreased by $25.8 \%$. The highest reduction in number of lateral roots seedlings was recorded in seeds soaked in cell-free medium from death phase (Table 1). While, the seeds soaked in cell-free medium from log phase showed a reduction in the number of lateral roots by $20 \%$ as compared to that of control. On the other hand, the fresh weight of roots and shoots of maize seedlings was decreased by $97.7 \%$ in cell-free medium from death phase and by 37.5 and $44.6 \%$ for cell-free medium from log phase as compared to that of the control (Table 1). Cell free-medium of M. aeruginosa in death phase 
decreased the dry weight of the root and shoot of maize seedlings by $99 \%$ as compared to that the control (Table 1). Also, cell-free medium from log phase reduced the dry weight of the root and shoot by 5.6 and $20.2 \%$ of that of the control after 8 days of germination. No leaves were formed for the seedlings from seeds that were soaked in cell-free medium from the death phase of $M$. aeruginosa. On the other hand, soaking seeds in cell-free medium from log phase reduced the leaf area by $23 \%$ as compared in that in the control (Table 1). This inhibition may be due to the presence of algal allelochemicals in the cell-free medium of M. aeruginosa (El-Sheekh et al. 2010). These allelochemicals which was produced and released by M. aeruginosa in the cell-free medium could be considered as one of the most important components in inhibiting growth and nutrient uptake of maize plant.

Table 1. Effects of extract of Microcystis aeruginosa on root and shoot lengths, number of lateral roots, fresh, dry weight of root and shoot, leaf area of 8-day-old of Zea mays seedlings.

\begin{tabular}{lllllllll}
\hline $\begin{array}{l}\text { Growth } \\
\text { phases }\end{array}$ & $\begin{array}{l}\text { Root } \\
\text { length } \\
(\mathrm{cm})\end{array}$ & $\begin{array}{l}\text { Shoot } \\
\text { length } \\
(\mathrm{cm})\end{array}$ & $\begin{array}{l}\text { No of } \\
\text { lateral } \\
\text { roots }\end{array}$ & $\begin{array}{l}\text { Fresh } \\
\text { weight of. } \\
\text { root }(\mathrm{g})\end{array}$ & $\begin{array}{l}\text { Fresh } \\
\text { weight of } \\
\text { shoot }(\mathrm{g})\end{array}$ & $\begin{array}{l}\text { Dry } \\
\text { weigh of } \\
\text { root }(\mathrm{g})\end{array}$ & $\begin{array}{l}\text { Dry weight } \\
\text { of shoot } \\
(\mathrm{g})\end{array}$ & $\begin{array}{l}\text { Leaf } \\
\text { area } \\
\left(\mathrm{cm}^{2}\right)\end{array}$ \\
\hline Control & 19.3 & 25.2 & 10 & 0.72 & 1.3 & 0.09 & 0.104 & 65.5 \\
& \pm 1.5 & \pm 1.6 & \pm 1.00 & \pm 0.13 & \pm 0.10 & \pm 0.01 & \pm 0.01 & \pm 17.0 \\
Log & 10.7 & 18.7 & 8 & 0.45 & 0.72 & 0.082 & 0.083 & 50.5 \\
phase & $\pm 0.5^{* * *}$ & $\pm 1.1^{* * *}$ & $\pm 0.57^{* * *}$ & $\pm 0.04^{(\mathrm{ns})}$ & $\pm 0.09^{* * *}$ & $\pm 0.008^{(\mathrm{ns})}$ & $\pm 0.01^{(\mathrm{ns})}$ & $\pm 11.2^{(\mathrm{ns})}$ \\
Death & 4.5 & 0.6 & 2 & 0.13 & 0.03 & $0.0008^{* * *}$ & 0.001 & 0 \\
phase & $\pm 0.5^{* * *}$ & $\pm .03^{* * *}$ & $\pm 0.57^{* * *}$ & $\pm .0005^{* * *}$ & $\pm 0.002^{* * *}$ & $\pm 0.00^{* * *}$ & $\pm 0.0003^{* * *}$ & $\pm 0^{* * *}$ \\
F value & 123.12 & 234.91 & 46.83 & 15.19 & 65.16 & 107.88 & 67.59 & 18.60 \\
p value & 0.0001 & 0.0001 & 0.0001 & 0.0011 & 0.0001 & 0.0001 & 0.0001 & 0.0006 \\
\hline
\end{tabular}

Each value is the mean of three readings \pm standard deviation. ${ }^{* * *}$ Highly significant at $\mathrm{p} \leq 0.001$ using one

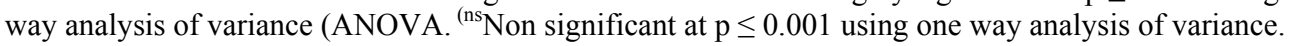

The present results demonstrated that the cell-free medium of $M$. aeruginosa in the death phase showed the highest inhibitory effects on maize than that from log growth phase. This result is in agreement with that of Pearson et al. (1990) which demonstrated that most of the toxin release occurred as cells age and died and was passively leaked, although active release of toxins can also occur from young growing cells. Release of microcystin into the extra cellular environment was attributed to the death and lysis of cyanobacterial blooms (Sivonen and Jones, 1999), so the amount of microcystins in culture medium in death phase is higher than in culture medium in log phase, then the cyanobacterial toxins (microcystins) could be used as allelopathic substances that have high significant negative effects.

As described by El-Sheekh et al. (2010) the amount of total phenolic compounds and alkaloids in cell-free medium in death phase is 686.97 and $0.25 \mathrm{mg} / \mathrm{l}$, respectively which is higher than in log phase. This may explain the inhibitory effect of the algal cell-free medium. Also phenolic compounds interfere to some degree with many vital processes, mineral uptake, respiration, photosynthesis, protein and chlorophyll synthesis. Nakano et al. (2004) reported that alkaloids showed growth inhibition against both mono- and dicotyledonous plants. Furthermore, these alkaloids exhibited higher activity against the growth of root than that of shoot of the plant species.

Soaking of maize seeds in cell-free medium of log phase of $M$. aeruginosa decreased chlorophyll $a$, chlorophyll $b$ and carotenoid content of seedlings by $67,65.4$ and $60.7 \%$, respectively as compared to control (Table 2). Saqrane et al. (2009) showed that cyanobacteria aqueous extract containing various MC variants caused a $22-25 \%$ decrease in chlorophyll $a, b$ content in maize and Lens esculenta following 30-day-exposure to 2.1 and $4.2 \mu \mathrm{g} / \mathrm{ml}$, but no significant effect on Triticum durum and Pisum sativum was observed. 
Generally, one way analysis of variance showed that, soaking of maize seeds in log and death phase cell-free medium revealed high significant effect on all growth parameters and all pigment fractions (chlorophyll $a$, chlorophyll $b$ and carotenoids) at ( $\mathrm{p} \leq 0.001)$, except leaf area, fresh weight of root and dry weight of both the shoot and root revealed no significant effect in the case of soaking seeds in $\log$ phase cell-free medium (Tables 1,2).

Table 2. Effects of seed soaking in the extract of Microcystis aeruginosa on photosynthetic pigments contents of 8-day-old Zea mays seedlings.

\begin{tabular}{|c|c|c|c|}
\hline \multirow[t]{2}{*}{ Growth phase } & Chlorophyll $a$ & Chlorophyll $b$ & Carotenoids \\
\hline & \multicolumn{3}{|c|}{ (mg/g/dry tissue) } \\
\hline Control & $1.198 \pm 0.17$ & $0.8398 \pm 0.13$ & $0.5415 \pm 0.07$ \\
\hline Log phase & $0.3959 \pm 0.04^{* * *}$ & $0.2903 \pm 0.04^{* * *}$ & $0.2128 \pm 0.02^{* * *}$ \\
\hline Death phase & $0 \pm 0.00^{* * *}$ & $0 \pm 0.00^{* * *}$ & $0 \pm 0.00^{* * *}$ \\
\hline F value & 94.47 & 64.42 & 94.49 \\
\hline $\mathrm{p}$ value & 0.0001 & 0.0001 & 0.0001 \\
\hline
\end{tabular}

Each value is the mean of three readings \pm standard deviation. ${ }^{* * *}$ Highly significant at $\mathrm{p} \leq 0.001$ using one

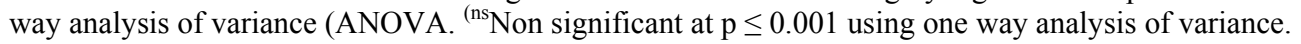

The different concentrations of crude extracts of $M$. aeruginosa reduced the root length of seedlings; increasing the concentration of microcystins crude extracts caused a decreased in the root length of maize seedlings (Table 3). The most pronounced reduction was detected in seedlings produced from presoaked seeds with $500 \mu \mathrm{g} / \mathrm{ml}$ crude extract by $73.5 \%$ as compared to control. However, no germination was detected with $800 \mu \mathrm{g} / \mathrm{ml}$ crude extract. The length of maize seedlings was reduced with the increase in the concentration of the toxin extract which ranged from 20 to $88 \%$ than that of the control value (Table 3). The number of lateral roots of maize

Table 3. Effects of different concentrations of microcystin crude extract of Microcystis aeruginosa in log phase on shoot, root lengths, number of lateral roots and percentage of germination of 4-dayold Zea mays seedlings.

\begin{tabular}{lllll}
\hline $\begin{array}{l}\text { Concentration } \\
(\mu \mathrm{g} \text { dry cells } / \mathrm{ml})\end{array}$ & $\begin{array}{c}\text { Root length } \\
(\mathrm{cm})\end{array}$ & $\begin{array}{c}\text { shoot length } \\
(\mathrm{cm})\end{array}$ & No. of lateral roots & \% germination \\
\hline Control & $9.44 \pm 0.7$ & $4.52 \pm 0.13$ & $6 \pm 0.7$ & $100 \pm 0.00$ \\
100 & $5.7 \pm 0.85^{* * *}$ & $3.6 \pm 0.45^{* * *}$ & $5 \pm 0.7^{* *}$ & $100 \pm 0.00^{\text {)ns }}$ \\
200 & $4.33 \pm 0.3^{* * *}$ & $1.8 \pm 0.2^{* * *}$ & $3 \pm 0.6^{* * *}$ & $76.66 \pm 5.8^{* * *}$ \\
300 & $3.1 \pm 0.53^{* * *}$ & $1.36 \pm 0.32^{* * *}$ & $0 \pm 0^{* * *}$ & $66.66 \pm 5.8^{* * *}$ \\
500 & $2.5 \pm 0.5^{* * *}$ & $0.56 \pm 0.05^{* * *}$ & $0 \pm 0^{* * *}$ & $53.33 \pm 5.8^{* * *}$ \\
800 & $0 \pm 0^{* * *}$ & $0 \pm 0^{* * *}$ & $0 \pm 0^{* * *}$ & $0 \pm 0^{* * *}$ \\
F value & 101.40 & 148.31 & 87.02 & 249.93 \\
$\mathrm{p}$ value & 0,0001 & 0.0001 & 0.0001 & 0.0001 \\
\hline
\end{tabular}

Each value is the mean of three readings \pm standard deviation. ${ }^{* * *}$ Highly significant at $\mathrm{p} \leq 0.001$ using one way analysis of variance (ANOVA. ${ }^{* *}$ Significant at $p \leq 0.001$ using one way analysis of variance (ANOVA).

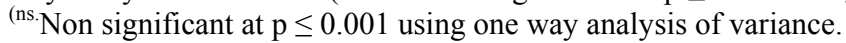

seedlings treated with 100 and $200 \mu \mathrm{g} / \mathrm{ml}$ microcystins crude extract was reduced by 16.6 and $50 \%$, respectively as compared to that of the control (Table 3 ). On the other hand, the extract at a concentration of $100 \mu \mathrm{g} / \mathrm{ml}$ showed the same percentage of germination of the control (without toxins) after 4 days of germination, whereas in seeds soaked in $800 \mu \mathrm{g} / \mathrm{ml}$ did not germinate. 
Maize seeds soaked in 200, 300 and $500 \mu \mathrm{g} / \mathrm{ml}$ microcystins crude extract showed a reduction germination by 23,33 and $47 \%$, respectively as compared to that of the control (Table 3 ).

One way analysis of variance showed that, soaking of maize seeds in different concentrations of microcystins crude extract of $M$. aeruginosa revealed a high significant reduction in all growth parameters $(\mathrm{p} \leq 0.001)$. However, the lowest concentration of crude extract $(100 \mu \mathrm{g} / \mathrm{ml})$ showed a significant effect $(p \leq 0.001)$ on the number of lateral roots and nonsignificant effect $(p>0.001$ or 0.05 ), it is preferable to add p-value exactly) on the percentage of germination compared to control (Table 3).

The seed soaked in death phase cell-free medium of M. aeruginosa showed more inhibitory effect on growth of maize than $\log$ phase. Different concentrations of microcystin crude extract $(200,300$ and $500 \mu \mathrm{g} / \mathrm{ml})$ decreased the percentage of germination of the seeds of maize while the concentration $800 \mu \mathrm{g} / \mathrm{ml}$ completely inhibited the germination of seeds after 4 days of growth (Table 3). These results are in agreement with those obtained by Pflugmacher et al. (2006) who reported that germination of alfalfa seeds was inhibited by both purified MCs and anatoxin-a from a toxic cyanobacteria bloom, and by a cell-free crude extract from the same bloom. KurkiHelasmo and Meriluoto (1998) showed that seed germination of Sinapsis alba was significantly reduced in the presence of MC-RR at concentration of $5 \mu \mathrm{g} / \mathrm{ml}$.

Microcystin crude extract decreased the root length of maize plant after four days of seedlings. The reduction increased by increasing crude extract concentrations. Peuthert et al. (2007) used an extract with mixture of MC-LF and LR to determine the effect of microcystins on several important agricultural plant species, the present study has clearly confirmed that, exposure to MCs crude extract containing MC-LR can induce firstly highly significant effect on the inhibition of germination and elongation of the primary root of $Z$. mays and inhibition effect increased by increasing the concentration of the crude extract from 100 to $800 \mu \mathrm{g} / \mathrm{ml}$. Present results are supported by Saqrane et al. (2008) which showed the effect of cyanbacteria aqueous extracts containing MC-LR exposure during four days strongly inhibits the germination of Pisum sativum seeds. Microcystins have a pronounced inhibitory effect on number of primary root, epicotyls length and the lateral root formation of maize (Table 3). Similar results were reported in white mustard seedlings by M-Hamvas et al. (2003).

In conclusion, this study shows the high toxic and cytotoxic influence of cyanobacterial extract containing microcystins on plant growth and supports the idea that, the use of surface water containing $\mathrm{MC}$ for irrigation can affect both plant crop yield and quality.

\section{References}

Allen MM and Stanier ST 1968. Selective isolation of blue-green algae from water and soil. J. Genetic Microbiol. 51: 302.

Chen J, Song L, Dai J, Gan N and Liu Z 2004. Effects of microcystins on the growth and the activity of superoxide dismutase and peroxidase of rape (Brassica napus L.) and rice (Oryza sativa L.). Toxicon 43: 393-400.

Codd GA, Metcalf JS and Beattie KA 1999. Retention of Microcystis aeruginosa and microcystin by salad (Lactua sativa) after spray irrigation with water containing cyanobacteria. Toxicon 37: 1181-1185.

El-Sheekh MM, Khairy HM and El-Shenody RA 2010. Allelopathic studies on the blue green alga (Cynobacterium) Microcystis aeruginosa. Allelopathy J. 26: 275-290.

Featonby-Smith BC and Van Staden Z 1983. The effect of seaweed concentrate and fertilizer on the growth of Beta vulgaris. Z. Pflanzenphysiol. 112:155-162.

Harada KI, Suzuki M, Dahlem AM, Baesley VR, Carmichael WW, Rinehart and KL 1988. Improved methods for purification of toxic peptides produced by cyanobacteria. Toxicon. 26: 433-439. 
Kurki-Helasmo K and Meriluoto J 1998. Microcystin uptake inhibits growth and protein phosphatase activity in mustard (Sinapis alba L.) seedlings. Toxicon. 36: 1921-1926.

Metzner H, Rau H and Senger H 1965. Untersuchunger, zur synchronisier barkei einzelner pigmentmangel mutanten von Chlorella. Planta. 65: 186-194.

M-Hamvas M, Máthé C, Molnár E, Vasas G, Grigorszky I and Borbély G 2003. Microcystin-LR alters the growth, anthocyanin content and single-stranded DNase enzyme activities in Sinapsis alba L. seedlings. Aquatic Toxicol. 62: 1-9.

Mohamed ZA and Al Shehri AM 2009. Microcystins in groundwater wells and their accumulation in vegetable plants irrigated with contaminated waters in Saudi Arabia. J. Hazard Material. 172: 310-315.

Nakano H, Nakajima E, Fujii Y, Shigemori H and Hasegawa K 2004. Structure activity relationships of alkaloids from mesquite (Prosopis juliflora (Sw.) DC. Plant Growth Regulators. 44: 207-210.

Pearson MJ, Ferguson AJD, Codd GA, Reynolds CS, Fawell JK and Hamilton RM 1990. Toxic blue-green algae. A report by the UK National Rivers Authority. Water Quality Series 2: 1-128.

Peuthert A, Chakrabarti S and Pflugmacher S 2007. Uptake of microcystins- LR and -LF (cyanobacterial toxins) in seedlings of several important agricultural plant species and the correlation with cellular damage (lipid peroxidation). Environ. Toxicol. 22: 436-442.

Pflugmacher S, Jung K, Lundvall L, Neumann S and Peuthert A 2006. Effects of cyanobacterial toxins and cyanobacterial cell-free crude extract on germination of alfalfa (Medicago sativa) and induction of oxidative stress. Environ. Toxicol. Chem. 25: 2381-2387.

Prescott GW 1978. How to Know the Fresh Water Algae, pp: 1-267. Brown Company Publishers Dubuque, IOWA, USA.

Saqrane S, El-Ghazali I, Oudra B, Bouarab L and Vasconcelos V 2008. Effects of cyanobacteria producing microcystins on seed germination and seedling growth of several agricultural plants. J. Environ. Sci. Health Part. B, Pesticides, Food contaminants, and agricultural wastes. 43: 443-51.

Saqrane S, Ouahid Y, El Ghazali I, Oudra B, Bouarab L and del Campo F 2009. Physiological changes in Triticum durum, Zea mays, Pisum sativum and Lens esculenta cultivars, caused by irrigation with water contaminated with microcystins: A laboratory experimental approach. Toxicon. 53: 786-796.

SAS program (1989-1996). Copyright (c. by SAS Institute Inc., Cary, NC, USA. SAS) r. Proprietary Software Release 6.12 TS020.

Shen PP, Shi Q, Hua ZC, Kong FX, Wang ZG, Zhuang SX and Chen DC 2003. Analysis of microcystins in cyanobacteria blooms and surface water samples from Meiliang Bay, Taihu Lake, China Environ. International 29: 641-647.

Sivonen K and Jones G 1999. Cyanobacterial toxins. In: Toxic Cyanobacteria in Water. A Guide to their Public Health Consequences, Monitoring and Management (Eds I. Chorus and J. Bartram., pp. 41-111. E. and F.N. Spoon, London. 